\title{
Urban human health: A study on food and drink phenomena
}

\author{
N. Athiroh*, M.I. Thohari \& A. Sa'dullah \\ Universitas Islam Malang, Malang, Indonesia
}

\begin{abstract}
This research explores food and beverage in Tlogomas Malang, Indonesia. We analyzed perception for food and drink with a social approach and examined borax, formalin, and the heavy metal content of food and beverages in terms of scientific policy. In so doing, both qualitative and quantitative methods were employed. Data was analyzed descriptively. Our identification of food products included 25 food stalls. Sixty foods tested contained borax and formalin, and only one type of food was detected positive for borax and formalin. Findings also suggest that 20 food samples $(1.67 \%)$ contained sauce, "terasi", and "petis are not dangerous. The heavy metal test was carried out on all types of food, namely 80 food samples, and 74 of the 80 food samples tested showed positive results for $\mathrm{Cu}$ (copper) with a percentage of $92.5 \%$. (copper). Meanwhile, 42 of the 80 food samples showed positive results for $\mathrm{Pb}$ (lead) with a percentage of $52.5 \%$ and showed negative results for other metals. The respondents in this research did not complain to vendors and managers. Also, the "Mamin" stall on campus has not been tested at the laboratory.
\end{abstract}

Keywords: food, drink, heavy metal, urban, human, health

\section{INTRODUCTION}

Based on an annual report of Indonesian religious life in 2020, the Indonesian Muslim population was approximately 209,12 million people. Thus, the percentage of Muslim people reaches $87 \%$ of the total population. The quantity of Muslims in Indonesia has made the country a potential market for halal products (Arifin 2016). The Islamic boarding school is the oldest Islamic institution in Indonesia, contributing to the religion and health fields. The Islamic boarding school also has a significant contribution to the use of halal products (Suharto 2018).

The culture in the Assalafiyah Islamic boarding school is not conducive to healthy eating habits. There are so many culinary cafes in the Islamic boarding school area that are cheap, easy to get, tasty, and suitable for people. Which makes them seem like an excellent choice. On the contrary, the food is known to cause food poisoning. The food must have been contaminated by microorganisms like E. colli or Salmonella sp, and contains "Rhodamine B" colouration in the sauce (Tatebe et al. 2014).

Researchers examined three samples of "tempura" based on all the positive samples' chemistry examination results of all the positive models that contained formalin and borax. A food additive was found to contain borax. Borax becomes toxic when it accumulates in the body. It causes vomiting, fatigue, and renal failure (Pongsavee 2009). Thereby, it is essential to consume halal food based on the Al-Qur'an (Al-Maidah: 88).

\section{METHODS}

The research employed both qualitative and quantitative methods. The qualitative approach included planning preparation, asking for consent and recruiting 50 respondents using a purposive sampling

\footnotetext{
${ }^{*}$ Corresponding author
} 
technique. A quantitative approach was used in the laboratory work, consisting of the formalin test, borax test, and colouration test.

\subsection{Research variable}

The variables included in this research were borax, formalin, and heavy metal of food and beverage, respondents' perception of food and drinks was measured using a Likert scale survey, with a social economy character for every individual consisting of age, sex, education, occupation, income, social status, respondents' communication for knowledge of food and beverages, social activity impact of food and beverages, and the distance of their home from food and drinks vendors (Baral 2017).

\subsection{Data collection}

The research employed both primary and secondary data. Primary data included a structuredinterview using a questionnaire, while the secondary data was gathered from document analysis (Baral 2017).

\subsection{Data analysis}

Qualitative data analysis used was an analysis of the inferential test. A hypothesis was proposed to examine a strong or weak relationship between two variables. The quantitative data was tabulated and analyzed using the Anova test (Onwuegbuzie et al.2014).

\section{RESULTS AND DISCUSSION}

The findings document 25 culinary cafes around the Islamic boarding school campus area, with kinds of food tested including deflated tofu ("tahu gembos"), chips ("kerupuk"), noodles, "sempol", sauce, tuna fish ("tongkol"), "lele" fish, "cilok", powdered spice, "cimol", meatballs, white tofu, suhun, powder, "pindang", "batagor", a condiment made from pounded and fermented shrimp and small fish ("terasi"), and a condiment of fermented fish or shrimp ("petis"), and "Bandeng" fish.

\subsection{Test of borax content}

Among the 60 foods that were tested, only one food showed contamination by borax in the percentage of $1.67 \%$. The danger of borax for the body includes decreasing body weight, vomit, slight diarrhea, appearing spot on the skin, hair falling out, convulsion, and anemia (Pongsavee 2009). Tumbel's (2010) research revealed that wet noodles circulating in Makassar City do not contain borax. Turkez et al. (2013) showed no increase in MNHEPs. Moreover, simultaneous treatments with BX significantly modulated the genotoxic effects of $\mathrm{AlCl}$ in rats. $\mathrm{BX}$ has beneficial influences and can antagonize Al toxicity (Turkez et al. 2013).

These findings are similar to previous research exploring meatballs with borax. The research found no harmful preservatives in the meatball and showed that borax was not found in beef meatballs. Borax had effects on immune cell proliferation (lymphocyte proliferation) and induced sister chromatid exchange in human chromosomes. The toxicity of borax may lead to cellular toxicity and genetic defects in humans (Pongsavee 2009). The most dominant factor relating to the behaviour of borax usage was health education given to all vendors. The stall vendors' OR value was 2.433 (CI: 90\% 1.108-5.342), which means that vendors who never receive health education tend to use borax 2.43 times as much compared to those who have received education (Mujianto et al. 2005). 


\subsection{Test of formalin content}

Among the 60 foods tested, only one food showed borax contamination, with a content of $1.67 \%$. The consumption limitation of food matter containing formalin according to the International Program on Chemical safety for an adults is $1.5-14 \mathrm{mg}$ per day. For food, $0.2 \mathrm{mg}$ may be eaten per day and for beverage, $0.1 \mathrm{mg}$ per liter of water per day. According to the Occupational Safety and Health Administration (OSHA). The Formalin threshold limitation is 1- $0.1 \mathrm{mM}$ generally (Warner 2013). Exposure to formaldehyde may cause leukemia, particularly myeloid leukemia, in humans. However, results from other investigations are mixed, suggesting caution in drawing definitive conclusions (Hauptmann et al. 2003).

\subsection{Test of colouration content}

We tested 20 samples of food such as sauce "terasi" and "petis" for colouration content. Among the 20 samples of food tested. The impact that occurs can be in the forms of eye irritation, digestive tract irritation and red urine. Most of the "terasi" samples (70\%) were found to contain Rhodamine B. Thirteen respondents (43.3\%) viewed Rhodamine B as having moderate risk. Most of "terasi's" creators $(63.3 \%)$ did not know about dangerous colour substances. Meanwhile, $63.3 \%$ of the respondents claimed that Rhodamin B is food colouring and is used to colour the "terasi". Adding Rhodamine B to "terasi's" colour makes it look more attractive. It means that most of the sellers have a positive attitude. It also implies that the respondents do not agree with using Rhodamine B for terasi.

This research showed that SF at the elementary school in Kulon Progo District contained excessive food additives and hazardous substances. In fact, $4 \%$ of the samples contained excessive sodium benzoate, sorbic acid, and $8 \%$ of the samples contained excessive sodium cyclamate's excessive artificial sweetener. SF with boric acid was 3\% samples ("cilok", "sosis", "kerupuk rambak") and formalin was $1 \%$ samples ("burjo", "cimol"). There was a significant correlation between the SF vendor's education level with knowledge about formalin, boric acid, and artificial sweetener.

\subsection{Test of heavy metal content}

The test of heavy metal by all kinds of food included 80 food samples taken from 25 cafes. In this regard, 74 out of 80 food tested showed positive results to $\mathrm{Cu}$ (Copper) with $92.5 \%$, while 42 of 80 food samples showed positive for $\mathrm{Pb}$ (lead) with $52 \%$ and indicated negative results for other metals. Many children suffer from heavy metal poisoning and this can cause nutrient deficiencies. Consuming heavy metal accumulation with a concentration degree of $100 \mathrm{mg} / \mathrm{dL}$ in child blood tends to cause severe disease, comas, convulsions, or death. Previous research revealed that heavy lead in the fish body has served as a contamination indicator.

Recently, many foods are circulated which are unsafe to consume. It is because of the metal contamination such as lead $(\mathrm{Pb})$, mercury $(\mathrm{Hg})$, arsenic $(\mathrm{As})$, and cadmium $(\mathrm{Cd})$. If those metals come into the human body through food, which is consumed by humans, it can cause nerve system problems, brain damage, paralysis, growth resistance, kidney damage, bone fragility, and DNA damage or cancer.

The primary source of lead $(\mathrm{Pb})$ pollution comes from vehicle emissions. Lead contaminations are at various environmental components such as air, water, the ground, and the food itself. Lead can enter the body of a human being through inhalation, ingestion, and through the skin. The different symptoms include infertility in men, trouble menstruating, miscarriages, and even death in women. Lead in a child's body tends to result in continuous anemia and intelligence degradation (Tchounwou et al. 2012).

\subsection{Analysis of perception to food and beverage using a social approach}

To collect respondents' perceptions, a set of questionnaires was distributed to lecturers, official employees, students, and other people (Baral 2017). This includes a) the respondents' description, 
b) the respondents' need for food and beverages, c) society's character, d) respondents' perceptions on culinary input, e) respondents' perceptions on leading product food and drink brands and byproducts from food, f) respondents' perceptions on wasted food and beverages, and g) respondents' perceptions on the impact of the culinary business food and beverages' existence.

In this research, we found that the respondents $(42.86 \%)$ never conveyed complaints to food and beverage vendors. Most of them (40\%) never contacted the vendors and the managers to convey their opinions. This happens due to reluctance since the group of food and beverage culinary leaders in halal, tayyib, and mubarak stalls never hold meetings with people $(71.43 \%)$.

Basically, the respondents strongly agree that the main products of food and beverage are of $40 \%$ safe ingredients; also supported by having hygiene and sanitation of $42.86 \%$. However, they $(34.29 \%)$ disagreed very much if the by-product is dangerous for the environment. They agreed $(31.43 \%)$ if the product is environmentally friendly. They $(37.14 \%)$ also agreed that if the production process paid attention to the halal aspect and agreed very much if the culinary food and beverages' production process does not cause contamination (28.57\%).

The respondents ( $40 \%$ ) disagreed with newcomers of culinary food and beverages as they created social distractions in the environment. They $(42.86 \%)$ also disagreed if criminality increases in the environment. They (48.57\%) agreed if Islamic boarding schools work to produce culinary food and beverages. They (40\%) agreed that a group of culinary food and bev erage producers help poor people. Our findings have portrayed that Islamic symbolisms have significant influences on the decision to buy food products. It is indicated by a significant p-value, which is $<0.005$. In other words, the influence of Islamic symbols on buying decisions is $27.3 \%$.

\section{CONCLUSION}

This research has attempted to unravel 25 cafes in the Islamic boarding school campus area with some food such as tofu "tahu gembos", chips "krupuk", noodle, "sempol", sauce, tuna fish ("tongkol"), "Lele" fish, meatball, white tofu, suhun, siomay, meatball of fish ("pentol") "cilok", powder spice, "cimol", "pindang", "batagor", "terasi", "petis", and "Bandeng" fish. Among the 60 tested foods, we found one food positivey-contained borax and formalin, with $1.67 \%$ each. Besides, our research portrayed 20 food samples, such as sauce, "terasi" and "petis" that were tested in terms of colouration content and revealed no endangered colouration in these foods. The massive metal test for all kinds of food included 80 food samples taken from 25 cafes, and 74 from 80 food samples tested showed positive to metal $\mathrm{Cu}$ (copper) with $92.5 \%$. In comparison, 42 from 80 food samples showed a positive result of metal $\mathrm{Pb}$ (lead) with $52.5 \%$ and indicated negative results for other metals. In this research, we also found that our respondents never complained and desired to contact the vendors, waiter/waitress, and managers.

\section{ACKNOWLEDGEMENTS}

We wish to thank the Laboratory of Halal Center, University of Islam Malang, and Ministry of Religious Affairs for providing this research grant through Penelitian Unggulan Integrasi Keilmuan scheme (PUIK/12/2016).

\section{REFERENCES}

Arifin, Tajul. 2016. "Misunderstanding of the Indonesian Human Rights Activists on the Application of the Death Penalty." Asy-Syari'ah 18(1):185-98. doi: 10.15575/as.v18i1.7607.

Baral, Uma Nath. 2017. “'Research Data' in Social Science Methods.” Journal of Political Science 17:82-104. doi: 10.3126/jps.v17i0.20515. 
Hauptmann, Michael, Jay H. Lubin, Patricia A. Stewart, Richard B. Hayes, and Aaron Blair. 2003. "Mortality From Lymphohematopoietic Malignancies Among Workers in Formaldehyde Industries." JNCI: Journal of the National Cancer Institute 95(21):1615-23. doi: 10.1093/jnci/djg083.

Mujianto, Bagya, Anny Victor Purba, N. Sri Widada, and Retno Martini. 2005. "Faktor-faktor yang Mempengaruhi Penggunaan Boraks pada Bakso di Kecamatan Pondok Gede-bekasi." Indonesian Bulletin of Health Research 33(4):20279.

Onwuegbuzie, Anthony J., R. Burke Johnson, and Kathleen Mt Collins. 2014. "Call for Mixed Analysis: A Philosophical Framework for Combining Qualitative and Quantitative Approaches." International Journal of Multiple Research Approaches. doi: 10.5172/mra.3.2.114.

Pongsavee, Malinee. 2009. "Effect of Borax on Immune Cell Proliferation and Sister Chromatid Exchange in Human Chromosomes." Journal of Occupational Medicine and Toxicology 4(1):27. doi: 10.1186/17456673-4-27.

Suharto, Toto. 2018. "Transnational Islamic Education in Indonesia: An Ideological Perspective." Contemporary Islam 12(2):101-22. doi: 10.1007/s11562-017-0409-3.

Tatebe, Chiye, Xining Zhong, Takashi Ohtsuki, Hiroki Kubota, Kyoko Sato, and Hiroshi Akiyama. 2014. "A Simple and Rapid Chromatographic Method to Determine Unauthorized Basic Colourants (Rhodamine B, Auramine O, and Pararosaniline) in Processed Foods." Food Science \& Nutrition 2(5):547-56. doi: 10.1002/fsn3.127.

Tchounwou, Paul B., Clement G. Yedjou, Anita K. Patlolla, and Dwayne J. Sutton. 2012. "Heavy Metals Toxicity and the Environment." EXS 101:133-64. doi: 10.1007/978-3-7643-8340-4_6.

Tumbel, Maria. 2010. "Analisis Kandungan Boraks Dalam Mie Basah Yang Beredar Di Kota Makassar." Chemica: Jurnal Ilmiah Kimia Dan Pendidikan Kimia 11(1):57-64. doi: 10.35580/chemica.v11i1.389.

Turkez, Hasan, Fatime Geyikoğlu, and Abdulgani Tatar. 2013. "Borax Counteracts Genotoxicity of Aluminum in Rat Liver." Toxicology and Industrial Health 29(9):775-79. doi: 10.1177/0748233712442739.

Warner, Melanie. 2013. Pandora's Lunchbox: How Processed Food Took Over the American Meal. Simon and Schuster. 